\title{
A Landmark in the History of Library Cooperation in America
}

$I^{P}$ THERE is anyone who yet remains unconvinced that the Library of Congress is in fact and deed our national library, let him reflect upon the achievements of the past year. Close upon the heels of a change in administration and in the midst of internal and external complexities of an unparalleled nature, the Library of Congress has shown to the world, both in the formulation of statesmanlike policies and in their execution, a quality of leadership commensurate with its exalted responsibilities. No other library in America had such opportunities for inspired leadership in this critical moment and no other could have in like manner supported its vision with equal resources. Its insistence upon a declaration of policy by the government that the contents of American libraries affect the national interest; its part in formulating the proposals for the consideration of UNESCO; its effectively planned and executed European mission; its distribution of several million texts and reference works to veterans; its initiation and implementation of the cooperative acquisitions project; its formulation of plans for publishing supplements to the Catalog of Books Represented by Library of Congress Printed Cards - these and many other extraordinary activities were projected in the interest of all American libraries. Vision, courage, and intelligence in high degree were needed to face the enormous difficulties that these enterprises involved.

\footnotetext{
1 Paper presented at the Conference of Eastern College Librarians, Columbia University, Nov. 30, 1946.
}

A timorous administration, or one frightened by political and practical obstacles, would have hesitated before such a Gargantuan program. The past year unquestionably marks the beginning of an era of immense potentialities in the world of librarianship and one of its most conspicuous promises is the enlightened position of leadership accepted by the Library of Congress in the interest of our whole library economy. This leadership was thrust upon it by force of circumstances and we who are its beneficiaries should be proud of the response of our national library to that challenge. Let its name remain the Library of Congress, but let us henceforth acknowledge it to be what it unquestionably is-our national library.

I begin with these general remarks even though the task assigned to me is to appraise the cooperative acquisitions project in a "critical rather than merely laudatory" manner. The cooperative acquisitions project, like other cooperative ventures, bristles with obvious weaknesses, imperfections, and inconsistencies. Yet a "merely critical" assessment would be as grave a distortion as one "merely laudatory." It would serve no useful purpose merely to point out faults that are as familiar to all those who have been in charge of the program as they are to those who have been its beneficiaries. If I criticize, then, it is only for the object of trying to find out what means we can take to eliminate weaknesses and faults in the future of library cooperation. Never- 
theless, whatever the deficiences of the cooperative acquisitions project itself, the Library of Congress deserves our applause for its vigorous leadership in this and many other areas.

I take it that we are all agreed upon certain fundamental principles of library cooperation. First, we cannot intelligently plan a sound national library economy, either in respect to growth or use, without abandoning individualistic, isolated, competitive patterns of librarianship. No library, whatever its resources, can be complete and selfcontained. Second, the objects of our concerted planning are, among other things, the establishment of an inventory of research materials now available in this country; the ordering of so comprehensive a national program of acquisition that henceforth at least one copy of every essential work of reference, wherever published, will be located in some American library; the acquisition by purchase or reproduction of the one-third or more of scholarly works of the past four hundred years of publishing which are not now to be found anywhere in this country; finally, and most important of all, the development of adequate indexes, guides, or controls-call them bibliographies or "memexes" or whatever-which will serve to guide the scholar, the professional man, or any other user of libraries through the welter of information and misinformation that man has accumulated.

\section{Means of Achieving Objectives}

While I think it true that librarians are generally agreed upon these basic assumptions, it does not follow that we are agreed upon the means of achieving our objectives. Many cooperative schemes among libraries have been advanced in the past half-century or so. Some of them, with limited objectives, have been conspicuously successful. Until now no comprehensive program touching the major objectives I have outlined has been able to gain much headway, first, because the competitive and duplicative pattern of higher education has necessarily imposed a similar pattern upon research libraries, and, second, because the individualistic character of scholarship has opposed itself to the programs of librarians. The latest and most generally discussed program of cooperation, the Farmington proposal, is distinguished by its realistic acceptance of this situation. In essence, the Farmington proposal hopes to achieve what the scholar wants, i.e., the securing of whatever book he happens to need, whenever he needs it, without touching either the educational pattern or attempting to alter the scholar's attitudes toward the problems presented by his resources. The Farmington proposal depends upon a wholly voluntary acceptance of responsibility by American research libraries in a concerted effort to plan the national library growth intelligently and adequately for the needs of American scholarship. It is not enough to proceed unhampered in our established educational programs and in our attitudes - there must be a positive acceptance of responsibility, a recognition of the interdependence of all libraries. Whether this compromise plan will succeed or not remains to be seen. Some of us are irreconcilable optimists, yet, though we have heard much brave talk of the unity of knowledge and the indivisibility of the world of learning in most of the programs of higher education in postwar America, we have observed with discouragement the almost total silence of all these programs on the subjects which to us seem essential to all education-the problem of the scholar in relation to the materials of scholarship.

In view of the appalling destruction of book resources on the continent of Europe and the remote possibility that anything 
resembling normal book trade would be established, many librarians, long before the cessation of hostilities, discussed plans for joint acquisition of scholarly resources as soon as conditions would permit. It was known that the supply of scientific and other literature produced in Europe between r 939 and 1945 would be small and the demand great. This demand for joint action on the part of American research libraries arose not merely out of a desire to avoid a competitive scramble in the book markets of the world, such as we experienced at the conclusion of World War I. It was recognized as well that the interests of European scholarship should be respected, and a self-imposed restraint was therefore required. Fortunately for research libraries in America, this point of view was held with strong conviction by the Librarian of Congress and his colleagues. As an agency of the federal government, the Library of Congress, having opportunities to place its representatives in controlled countries long before the ordinary channels of commerce were open, might have pursued an individualistic policy. It did not choose to do so, preferring to set the interests of all libraries above those of any one library.

On July 17, 1945, the Librarian of Congress addressed to the Secretary of State a letter that deserves to rank with the very first documents in the history of library statesmanship. Confronted with the problem of securing books and other library materials from foreign countries where the channels of trade were "not adequate to the task of supplying American research libraries with the material which they require for responding to the needs and deman'ds of scholarship, industry, and the government" the Librarian of Congress proposed that "the possibility be explored of making use for this purpose of certain of the facilities which are at the command of the Library of Congress and other government libraries for the development of their own collections." The Librarian of Congress suggested that if the Department of State should perceive no objections to the purchase by the Library of Congress in foreign countries of multiple copies of books, periodicals, newspapers, maps, etc., for the large research libraries of the United States, the Library of Congress would be glad to explore the possibility of securing the necessary joint purchasing agreements, financing the purchases, and distributing the copies received according to some plan which would best serve the national interest. This proposal was made by the Librarian of Congress "because of the deep conviction based upon daily experience, that the national interest, both in time of war and in time of peace, is intimately affected by the holdings of the large research libraries." To this enlightened proposal the Department of State replied, through Assistant Secretary Archibald MacLeish, with what appears to be the first declaration of policy by the government "that the national interest is directly affected by the holdings of many of the private research libraries." The Department of State therefore interposed no objections in principle to the employment of federal government facilities to assist in maintaining these specialized collections where the normal channels of acquisition were inoperative. Nevertheless, this declaration of policy was accompanied by certain conditions precedent: it would be necessary for the private research libraries to give assurances that they had agreed upon and carefully planned a program of cooperative buying and that such a plan would be supported by the benefiting libraries as long as federal assistance was employed.

This proposal by the Librarian of Congress and conditional acceptance by the Department of State inaugurated, under 
conditions of appalling complexity, a program which I venture to predict will become a landmark in the history of cooperative efforts of American libraries.

\section{Plan Put into Effect}

With this declaration of governmental policy in hand, the Librarian of Congress addressed a communication on Oct. I5, 1945, to several hundred American research libraries announcing that the Librafy of Congress was willing to assume the burden of handling the fiscal arrangements with the Department of State and in other ways to facilitate the program. In addition to this plan for buying foreign publications, the Librarian of Congress announced his willingness to utilize the cooperative mechanism of distribution for the purpose of placing in American libraries several hundred thousand copies of foreign publications that had become available for distribution chiefly from French, German, Italian, and Latin American sources. Representatives of the American Library Association, of the Association of Research Libraries, and of various governmental libraries met with the Librarian of Congress to plan this program. They agreed that it was essential to have the program of distribution planned by a group generally representative of the library and research interests of the country. Such a group was formed, headed by Robert Bingham Downs and composed of representatives of the American Library Association, the Association of Research Libraries, the American Council of Learned Societies, the Joint Committee on Importations, the $\mathrm{Na}$ tional Research Council, the Social Science Research Council, and the American Council on Education. This Committee to Advise on the Distribution of Foreign Acquisitions was requested to draw up a schedule of allocation by subject and by priorities in first, second, third copies, etc., of recent foreign books which might become available. In announcing the formation of this committee, the Librarian of Congress made it perfectly clear that libraries wishing to participate in the program would be given priorities by the committee in accordance with, first, the strength of individual libraries in particular subject fields; second, their willingness and ability to assume responsibility for acquisition in these subject fields; and third, their ability to give general service (including interlibrary loan service and, whenever possible, photocopying service) to the users of the materials thus acquired.

The unenviable task that fell to this committee in the next few months was that of assigning some 8,000 priorities to $\mathrm{I}_{5} \mathrm{li}$ braries in 254 subject fields. At the Chicago meeting of the Association of Research Libraries on December 29-30, the chairman of the committee reported that every subject of the entire group classification had been wanted by at least 3 libraries and some subjects had been checked for priority by as many as 46 . He further reported that assignments of priorities would be made on. the basis of several criteria: (a) strength of existing holdings, (b) location of highest priorities among geographical areas, (c) rotation of high priorities among different institutions in the same region so as to prevent undue concentration in a few libraries, (d) current research and publications of institutions as well as current appropriations for new books, (e) bibliographical centers where there were well-developed plans for cooperative buying, (f) libraries assuming responsibility for an entire field would be favored against those assuming responsibility for a subdivision thereof. At this meeting, one of the delegates asked the chairman of the committee whether an institution requesting a given field assumed a commitment for continuing to purchase in that field in 
the future. Mr. Downs' replied that libraries having first priority would definitely assume such an obligation, although, of course, this obligation could not be legally enforced. It was urged in the discussion that followed that the committee should attach high importance to the assignment of priorities on the basis of a "future agreement by the library to continue acquisition in the subject assigned."

\section{Fundamental Weakness}

Here then we come to the fundamental weakness of the cooperative acquisitions project: no continuing commitments were exacted as an essential condition of high priority. No doubt this was due to the emergency nature of the enterprise and to the fact that the committee simply did not have time to negotiate with its constituencies and to allow them in turn to negotiate with their authorities in order to bring forth such commitments. Legal and other obstacles to the making of binding commitments would have consumed so much time that the opportunity would have passed if this had been done. It is doubtful whether all participating libraries understood clearly that they were expected to assume a moral obligation for continuing to purchase in the field in which they had been awarded high priority. Nevertheless, whatever the extenuating circumstances, we cannot escape the conclusion that any permanent program of cooperative acquisition will prove chimerical if it follows the precedent here exhibited in the emergency project. So long as we aim at a framework of national acquisition through voluntary and self-imposed obligation, our efforts will fail unless we are willing to assume a continuing responsibility, regardless of whether this responsibility continues to coincide with our Jocal requirements. If such voluntary assumptions of continuing responsibility had been forthcoming, no doubt the task of awarding priorities would have been greatly simplified and no doubt also the results would have been less susceptible of criticism.

\section{No Flexibility in Priorities}

On July 22, 1946, the Library of Congress announced the "order of priorities in distribution" which, it said, was the result of the "conscientious and informed judgment of a committee representative of the broadest interests of research." With this appraisal there can be no quarrel. But in announcing the schedule, the Library of Congress made this statement: "Criticism of the schedule is invited; but, since it is obviously not feasible to reopen the matter of assignment for the purpose of the present project, it is hoped that criticism will be of a kind which may be usefully applied to later and more permanent attempts in the field of cooperative acquisitions." Here we come to the second notable weakness of the present plan-an understandable and perhaps unavoidable weakness, but a weakness nevertheless. Conscientious and informed though the committee were, and though they applied logical and reasonable criteria, it is nevertheless true that, first, it was not the constituency but the committee that established the criteria, and second, once the committee had spoken on the matter of priorities, it was "obviously not feasible to reopen the matter of assignment." In short, there was little opportunity for discussion and agreement on criteria, particularly the important one of an assumption of continuing responsibility, and there was no opportunity whatever to appeal from the judgment of the committee once a priority had been assigned. Obviously, this weakness proceeded from the emergency nature of the program, yet, before we can enter upon any permanent, planned program on a national basis, each participating institution must know well in advance and 
as precisely as possible what its opportunities and responsibilities are.

\section{Class Number 188}

It was the publication of the order, of priorities and distribution that brought forth the most vociferous criticism of the project. This criticism from heads of participating libraries was greatly magnified and intensified as soon as members of their faculties began examining the books themselves. Class Number 188, for which 36 institutions had requested priorities, soon became the focus of almost all criticism. This class, German literature, naturally included enough copies in most cases to be distributed to all of the participating libraries and not merely to those that had requested priorities in this classification. The result, particularly for many of the college libraries, was distressing. These institutions, by and large, had received low priorities in some of the more competitive classifications, such as art and the natural sciences. They were therefore receiving considerable quantities of novels and other vehicles of Nazi ideology, materials that their faculties in German literature regarded as beyond the pale even if literature were defined in the broadest terms. But they were not receiving, as a compensatory reward, the more important works for which the supply was drastically limited. Some of the larger research libraries, having high priorities in the more competitive classifications, received these large quantities of so-called German literature more complacently; they were assured that this shoddy reflection of the Nazi mind, classed as German literature and distributed to all participants in the project, would be, for them, offset by more desirable acquisitions in other priorities. But the professors of German literature in colleges and universities alike viewed the increasing piles of Class Number I88 with almost uniform scorn, some sug- gesting that it be burned, others that it be thrown in the wastebasket, and still others that it be returned whence it came.

Though Class Number 188 need not detain us in a critical appraisal of the project, since obviously the criticism it brought forth will scarcely be pertinent in any long-range cooperative program, I nevertheless pause to make two observations. First, even the shoddiest of Nazi literature is not totally worthless for scholarly research. On the contrary, the materials gathered under Class Number 188 may be of considerable importance to the psychologist delving into the motivations of human behavior, to the student of propaganda, to the musicologist for the study of the use of music as propaganda, to the historian, and to many other specialists in the lower reaches of human kind. Before the professor of German literature is allowed to send this material to the pulp mill, therefore, I would suggest that other disciplines not limited by preconceptions as to what constitutes literature, particularly the historians, be allowed to pass judgment.

\section{Order Number 4}

Second, the materials gathered under Class Number 188 enter into the cooperative acquisitions program and are distributed tó all participating libraries, not because of any joint purchasing effort of American libraries, but as a result of one of the most shameful denials of the principles of free inquiry ever made in the name of democracy. This travesty of the Bill of Rights was Order Number 4 of the Allied Control Authority, which was signed in Berlin on May 13, 1946. By this and subsequent regulations, all owners of circulating libraries, bookshops, bookstores, and publishing houses, state and municipal libraries, and libraries of universities, secondary schools, and academies, were ordered to remove from their possession all books, pamphlets, mag- 
azines, files of newspapers, albums of photographs, manuscripts, documents, maps, plans, song and music books, cinematographic films and magic lantern slides, including, in the words of Order Number 4, "everything intended for children of all ages," the contents of which embraced Nazi racial, militaristic, or imperialistic propaganda, antidemocratic or antireligious ideas, or attempted to divide or create disrespect for the United Nations, or to interfere in any way with the process of military government. These directives not only brought forth the seizure of such Nazi materials but also effectively prevented further publication of books and periodicals containing such proscribed ideas. The preamble to Order Number 4 contains the philosophy on which this far-reaching act of suppression was based: "Bearing in mind the danger presented by the National Socialist doctrine and in order to eradicate as soon as possible National Socialist, Fascist, militarist and anti-democratic ideas in all forms in which they found expression throughout Germany," the Allied Control Council proceeded with its regulations. Thus three centuries after John Milton wrote Areopagitica and more than a century and a half after we incorporated the Bill of Rights in our substantive law, we, in the name of democracy and in the face of all historical precedent, subscribed to the essentially Nazi belief that ideas can be suppressed by suppressing books. Instructions for the disposal of such seized materials, issued by the U.S. Office of Military Government for Germany on Sept. 10, 1946, by implication underscored the identity between the philosophy of Order Number 4 and the philosophy of Nazi Germany when, in providing for the pulping of German publications, these instructions underscored the statement that "under no conditions will any of the materials collected be burned."
The difference between the burning and pulping of books would scarcely be discernible to such a devout exponent of the principles of free inquiry as Thomas Jefferson, whose countrymen, acting in conjunction with the representatives of other nations, have thus betrayed one of the cardinal beliefs held and defended by the spokesman for American democracy. The New York Times condemned Order Number 4 as "a way of making the Nazis martyrs," and the President and Executive Secretary of the American Library Association sent telegrams of protest to President Truman and other officials in Washington. But most of our literary and learned journals passed the matter over in silence and Order Number 4 and the regulations for carrying out its philosophy continue to affront the beliefs on which libraries rest.

\section{Return German Materials}

I agree, therefore, with the professors of German literature who think that materials received in Class Number 188 should be returned, but not for the reasons they give. These materials, seized without moral or intellectual justification, perhaps even without legal justification, should either be returned or evaluated and provision be made for compensation. At the least, Order Number 4 and the philosophy on which it is based, should receive the most emphatic protest which we are capable of giving, should be rescinded, and at least some of the copies of German publications that are now cluttering up the cooperative acquisitions project should be returned to Germany. It would be well also if these evidences of the false promises and false hopes held out by Nazi leaders should be made required reading for German youth. At any rate, we are obligated to the European Mission of the Library of Congress and to some officials in the Allied Military Government for the 
fact that the entire mass of -Nazi books seized in German libraries and bookshops was not destroyed in the pulp mill through misguided zeal.

\section{Too Few Classifications}

The third major weakness of the cooperative acquisitions project arises from the fact that the number of classifications was too small. In any permanent system of cooperative division of responsibility, there must be a narrower definition of subjects. Under the present project, the University of Pennsylvania, with the distinguished Lea Library among its collections, was not able to receive books on the Inquisition because it was unwilling to accept responsibility for everything in Class Number 19; Massachusetts Institute of Technology received a very low priority in mechanical engineering, although it contains one of the best collections on this subject in the country; and Princeton, with a strong position in art and architecture, fell into a similar low priority because it did not request an entire subject classification. In many cases, despite the fact that the committee gave due publicity to the matter, some librarians evidently did not understand that willingness to take a whole classification was one of the major requisites for a high priority. Moreover, a single subject in the present list of classifications sometimes received greater subdivision than other perhaps equally important subjects. Philosophy, for example, is divided into four categories but medicine is confined to a single group. Consequently, a library specializing in dentistry was handicapped as to priority unless it was willing to take the entire category of medicine.

Although most of the dissatisfaction with the cooperative acquisitions project arises, in the final analysis, because the number of copies is small and the demand is great, it is not likely that this condition will prevail in any long-range program for a division of responsibility among libraries. For current books we may assume that, in general, a sufficient number of copies will be available for the necessary amount of duplication. Nevertheless, it is obvious that in any longrange program we shall need a much larger number of classifications. We shall also need to realize that such a program, to be feasible, must be a positive assumption of responsibility as well as a negative willingness to refrain from competition where the supply of copies is small. It has been generally said that the Farmington proposal would not restrain any library from acquiring any books it wishes to acquire. Nevertheless, in any exploration of the possibilities of that proposal we should remember the circumstances under which the cooperative acquisitions project has been carried outthat is to say, when copies of a given work are severely limited, priorities should be established according to some logical and natural scheme. Whether these priorities are imposed according to the criteria established by the Downs committee or by other standards, it will nevertheless be necessary on occasion for some libraries to yield in favor of others.

Naturally when the book trade of the world has returned to something approaching normal, this negative aspect of cooperation will dwindle to relative insignificance. But always, in normal or abnormal times, the one inescapable feature of a planned program of acquisitions for the country as a whole will be present- the necessity of commitments assuming responsibility for given subjects, however narrowly defined. Let it be remembered, too, that when this responsibility is assumed, our faculties will inevitably point to the trivia and trash that such categories include. This should not deter us in our comprehensive planning. Rather, it should bring to us the realization of the 
necessity of pointing out to our scholars the immense gaps that at present exist under haphazard and unplanned methods of library growth. The study of "Research Library Acquisitions from Eight Countries" by Edwin E. Williams in the Library Quarterly, October 1945, p. 313-23, show some of the lamentable results of our former individualistic policies, imposed upon us for the most part by scholars who have not given the same amount of attention to the total problem that librarians have given. A weakness of the cooperative acquisitions project and of all other proposals for planned library growth is the fact that we have not yet educated the educators to the importance of these proposals.

\section{A Gigantic Project}

Some of us have been privileged to inspect the vast mechanism of the cooperative acquisitions project. More than six thousand wooden packing cases full of books, gathered from many repositories in Europe, transported to America, opened, divided into categories, correlated with the system of priorities established by the committee, and dispatched to II5 participating libraries, make an impressing spectacle. More than a million pieces of literature will have passed through this mechanism before the project is completed. When we remember that every book, and, what is worse, every issue of every periodical, has to be recorded and assigned to a participating library, we gain a new appreciation of the immensity of the task of distribution assumed by the Library of Congress. Whatever wę may say about the defects and inequalities of the projectand there is much more that might be saidit is nevertheless true that the Library of Congress is carrying to completion an enterprise that stands as a great landmark in the fast-growing movement toward greater cooperation among American research libraries.

\section{New Courses in Columbia Summer Session}

The School of Library Service, Columbia University, announces two new courses in its summer program, July 7-August 15. Julia Wright Merrill, former chief of the Department of Information and Advisory Services of A.L.A., will conduct a course in rural, county, and regional libraries. Combined with offerings in rural sociology and rural education which will be available on the Columbia campus, this course affords an unusual opportunity for librarians interested in the growing field of library extension. The second course is a revival by Ernest J. Reece, Melvil Dewey Professor at Columbia, of his former seminar in education for librarianship. This offering is intended for library school graduates who have had some experience in teaching or who have a definite interest in joining a library school faculty. Parallel courses . will be available at Teachers College in curriculum development and teaching methods.

The new courses in rural libraries and education for librarianship are in addition to the offerings in the bachelor of science and master of science programs regularly scheduled for the summer session. 